\title{
Energy Coupling During Sulphur Compound Oxidation by Thiobacillus sp. Strain C
}

\author{
BY D. P. KELLY \\ Microbiology Department, Queen Elizabeth College, London, W.8 \\ AND P. J. SYRETT \\ Department of Botany, University College, London, W.C.1
}

(Received 8 October 1965)

\section{SUMMARY}

The addition of either sulphide or thiosulphate to an aerobic suspension of a Thiobacillus was followed within 10 sec. by the synthesis of intracellular ATP. The ATP formation accompanying sulphide oxidation was strongly inhibited by $0 \cdot 1 \mathrm{~mm}-2,4$-dinitrophenol, but that accompanying thiosulphate oxidation was unaffected. The presence of carbon dioxide had no effect on ATP formation or on the steady-state concentration attained. 2,4-Dinitrophenol did not significantly affect oxygen uptake nor the kinetics of thiosulphate oxidation but it inhibited carbon dioxide fixation with either sulphide or thiosulphate as substrate. It is concluded that sulphurcompound oxidation can be coupled to two different types of phosphorylation, only one of which is sensitive to 2,4-dinitrophenol. In the presence of 2,4-dinitrophenol and with thiosulphate as substrate, carbon dioxide fixation was not limited by the availability of ATP but might be limited by the availability of reduced nicotinamide adenine dinucleotides.

\section{INTRODUCTION}

Organisms of the genus Thiobacillus obtain energy from the oxidation of reduced inorganic sulphur compounds. The coupling of this energy to synthetic reactions has long been thought to be mediated by high energy phosphate compounds (Vogler \& Umbreit, 1942); recent work supports the view that ADP, ATP and reduced coenzymes are involved (Trudinger, 1956; Vishniac \& Santer, 1957; Milhaud, Aubert \& Millet, 1957; Johnson \& Peck, 1965). Peck (1960, 1962) used cell-free extracts of Thiobacillus thioparus, and suggested that thiosulphate was first split reductively to sulphide and sulphite, the sulphite being oxidized subsequently to sulphate by reactions which produce $A D P$ by a substrate-level phosphorylation, with adenosine $5^{\prime}$-phosphosulphate as an intermediate. This phosphorylation is insensitive to 2,4-dinitrophenol (DNP; Peck \& Fisher, 1962).

By using ${ }^{14} \mathrm{CO}_{2}$-fixation as a measure of energy transfer in the presence or absence of DNP, we obtained results which suggested that both DNP-sensitive and DNPinsensitive phosphorylations accompany thiosulphate oxidation, but that DNPsensitive phosphorylations are more important during sulphide oxidation (Kelly\& Syrett, 1964a). We now present further evidence, from measurements of the ATP content of intact bacteria, for the occurrence of both DNP-sensitive and DNPinsensitive phosphorylation during sulphur-compound oxidation, and for the greater 
importance of the former in sulphide oxidation. Our results also support the view that the reduced coenzymes necessary for $\mathrm{CO}_{2}$-fixation are generated by an energydependent reduction by electrons from reduced cytochromes, similar to that shown in other autotrophs (Aleem, Lees \& Nicholas, 1963) and recently reported for T. novellus by Aleem (1965).

A brief report of some of the present work has appeared elsewhere (Kelly \& Syrett, 1964b) and the background to the problem was discussed more fully by Kelly (1965).

\section{METHODS}

The organism. Thiobacillus sp. strain $\mathbf{c}$ was grown as described previously in media containing $1 \cdot 2 \%(\mathrm{w} / \mathrm{v}) \mathrm{Na}_{2} \mathrm{~S}_{2} \mathrm{O}_{3} .5 \mathrm{H}_{2} \mathrm{O}$ (Kelly \& Syrett, 1964a). Organisms were harvested by centrifugation, washed and suspended in $0 \cdot 1 \mathrm{M}$-sodium phosphate buffer (pH 7.0) to give dense suspensions usually containing about equiv. $3 \mathrm{mg}$. dry wt. organisms $/ \mathrm{ml}$.

Extraction and assay of ATP. Samples (2-3 ml. of dense suspensions were extracted with $0.2 \mathrm{ml} .14 \cdot 5 \%(\mathrm{w} / \mathrm{v})$ perchloric acid on ice for $10 \mathrm{~min}$., then brought to $\mathrm{pH} 7 \cdot 4$ by the addition of $1.0 \mathrm{ml}$. of $\mathrm{KOH}$ of suitable concentration. The clear supernatant solution was pipetted from the perchlorate precipitate. ATP was measured by a firefly luminescence method (Strehler \& Totter, 1952). The following were mixed in a $1.5 \mathrm{ml}$. cuvette at $20^{\circ}: 0.5 \mathrm{ml}$. $0.1 \mathrm{M}$-sodium arsenate + sulphuric acid buffer (pH 7.4); $0.3 \mathrm{ml}$. distilled water; $0.2 \mathrm{ml}$. perchlorate extract; $0.04 \mathrm{ml} .20 \%(\mathrm{w} / \mathrm{v}$ ) $\mathrm{MgSO}_{4} \cdot 7 \mathrm{H}_{2} \mathrm{O}$. The reaction was initiated by rapidly adding $0.1 \mathrm{ml}$. of an extract of firefly tails in $0.1 \mathrm{~m}$-arsenate $+\mathrm{H}_{2} \mathrm{SO}_{4}$ buffer ( $\mathrm{pH} 7 \cdot 4$ ) containing $2 \%(\mathrm{w} / \mathrm{v}$ ) $\mathrm{MgSO}_{4} .7 \mathrm{H}_{2} \mathrm{O}$. The light emission peak was measured 20 sec. later in a 'Locarte' fluorimeter. The enzyme preparation and samples were kept on ice and allowed to warm only when assayed. Perchlorate depressed the luminescence, apparently by interfering with the enzyme reaction rather than by destroying ATP. In the presence of a constant amount of perchlorate, light emission was proportional to the amount of ATP in solution. ATP standards and samples were always assayed in the presence of equivalent amounts of perchlorate. Comparison of the ATP content estimated by this method with the content determined in similar samples extracted by boiling the organisms for 30 sec. in $90 \%(v / v)$ ethanol in water, showed no significant difference. Bacterial extracts contained no substances other than perchlorate which interfered with the assay. DNP caused no interference. Data supporting these statements have been given elsewhere (Kelly, 1965).

Simultaneous determination of $\mathrm{ATP}$ content and ${ }^{14} \mathrm{CO}_{2}$ fixation. When the ATP content only was required, suspensions of bacteria were aerated in a rapid sampling device (Syrett, Bocks \& Merrett, 1964), or were shaken in $50 \mathrm{ml}$. conical flasks. When the ATP content and ${ }^{14} \mathrm{CO}_{2}$-fixation values were required simultaneously, bacterial suspensions $(2-2 \cdot 6 \mathrm{ml}$.) were shaken in $50 \mathrm{ml}$. conical flasks sealed with vaccine stoppers. Substrates $\left(\mathrm{KH}^{14} \mathrm{CO}_{3} ; \mathrm{Na}_{2} \mathrm{~S}_{2} \mathrm{O}_{3} ; \mathrm{Na}_{2} \mathrm{~S}\right)$ were injected into the flasks and the bacteria killed by injecting perchloric acid. Samples of the neutralized extracts were mixed with equal volumes of $5 \%(v / v)$ acetic acid in ethanol, and were used to estimate ${ }^{14} \mathrm{CO}_{2}$-fixation as described by Kelly \& Syrett (1964a). The rest of the material was assayed for ATP. For time-course experiments it was better to set up a series of such flasks and to kill the bacteria after various time intervals 
rather than to take a series of samples from a single flask with syringes. The latter method gave erratic values for ATP.

Gas exchange was measured by Warburg manometry.

Oxidation of radioactive thiosulphate was followed by the sampling and chromatographic methods described by Kelly \& Syrett (1966).

Chemicals. $\mathrm{Na}_{2}{ }^{14} \mathrm{CO}_{3}$ and $\mathrm{Na}_{2}\left({ }^{35} \mathrm{~S} . \mathrm{SO}_{3}\right)$ were obtained from the Radiochemical Centre, Amersham, Bucks; ATP (disodium salt; 3-4 $\mathrm{H}_{2} \mathrm{O} ; 99-100 \%$ ) and desiccated firefly lanterns from the Sigma Chemical Company; hexokinase from L. Light and Co., Colnbrook, Bucks. Other reagents were 'AnalaR' or of the best quality marketed. Solutions of $\mathrm{Na}_{2} \mathrm{~S}_{2} \mathrm{O}_{3}$ and $\mathrm{Na}_{2} \mathrm{~S}$ were always prepared immediately before use; washed crystals of $\mathrm{Na}_{2} \mathrm{~S}$ were used.

\title{
RESULTS \\ $\boldsymbol{A T P}$ formation during sulphide and thiosulphate oxidation, and the effect of 2,4-dinitrophenol
}

The bacterial ATP content increased at least twofold within 10-20 sec. after the addition of sulphide or thiosulphate (Fig. 1; and Kelly \& Syrett, 1964b). Low concentrations of DNP had little effect on the ATP increase during thiosulphate oxidation, while the same DNP concentrations severely depressed ATP formation after sulphide addition. Figure 1 demonstrates that this lower sensitivity of thiosulphate-dependent ATP formation to DNP inhibition was exhibited over a wide range of DNP concentrations. For example, $0.1 \mathrm{mM}-\mathrm{DNP}$ completely inhibited increase in ATP content when sulphide was oxidized, while the ATP formation with thiosulphate was unaffected by this concentration. Table 1 shows that treatment of the bacterial extracts with glucose and hexokinase virtually abolished the light emission, indicating the material determined by the firefly method was exclusively ATP.

\section{Table 1. Effect of treating thiobacillus extracts with hexokinase} and glucose before assaying for $A T P$

\begin{abstract}
Samples taken at intervals after addition of thiosulphate to dense bacterial suspensions were extracted with perchloric acid (see text). Two series of cuvettes were prepared, each cuvette containing in $0.9 \mathrm{ml}$. $50 \mu$ moles arsenate $+\mathrm{H}_{2} \mathrm{SO}_{4}$ buffer (pH 7.4); $10 \mu$ moles $\mathrm{MgCl}_{2} ; 0.2 \mathrm{ml}$. bacterial extract; $20 \mu$ moles glucose. Series 1 received no further addition; series 2 received $0.5 \mathrm{mg}$. hexokinase. Both series were incubated at $23^{\circ}$ for 16 min., then the ATP estimation was made as usual by adding $0.1 \mathrm{ml}$. firefly extract to each cuvette. Mean values from duplicates or triplicates are given.
\end{abstract}

\begin{tabular}{|c|c|c|}
\hline \multirow{2}{*}{$\begin{array}{c}\text { Sample time } \\
\text { after } \\
\text { thiosulphate } \\
\text { addition (min.) }\end{array}$} & \multicolumn{2}{|c|}{$\begin{array}{l}\text { ATP content ( } \mu \text { moles/g. dry wt. } \\
\text { bacteria) }\end{array}$} \\
\hline & -Hexokinase & + Hexokinase \\
\hline Initial & 1.57 & $0 \cdot 18$ \\
\hline $\begin{array}{l}0.33 \\
1.5\end{array}$ & $\begin{array}{l}4 \cdot 17 \\
4.00\end{array}$ & $\begin{array}{l}0.23 \\
0 \cdot 23\end{array}$ \\
\hline 3.0 & $\mathbf{3} \cdot 42$ & $0 \cdot 17$ \\
\hline $6 \cdot 0$ & $4 \cdot 68$ & $0 \cdot 18$ \\
\hline
\end{tabular}




\section{$\boldsymbol{A T P}$ formation in the presence or absence of carbon dioxide}

Initial experiments to measure ATP were made in the absence of $\mathrm{CO}_{2}$. However, Fig. 2 shows that even the presence of $\mathrm{CO}_{2}$ in high concentrations had little effect on the kinetics of the thiosulphate-dependent ATP increase. Since the presence of $\mathrm{CO}_{2}$ did not abolish the increase in ATP content it was possible to measure simultaneously $\mathrm{CO}_{2}$-fixation and ATP content of single samples taken over a period of time.

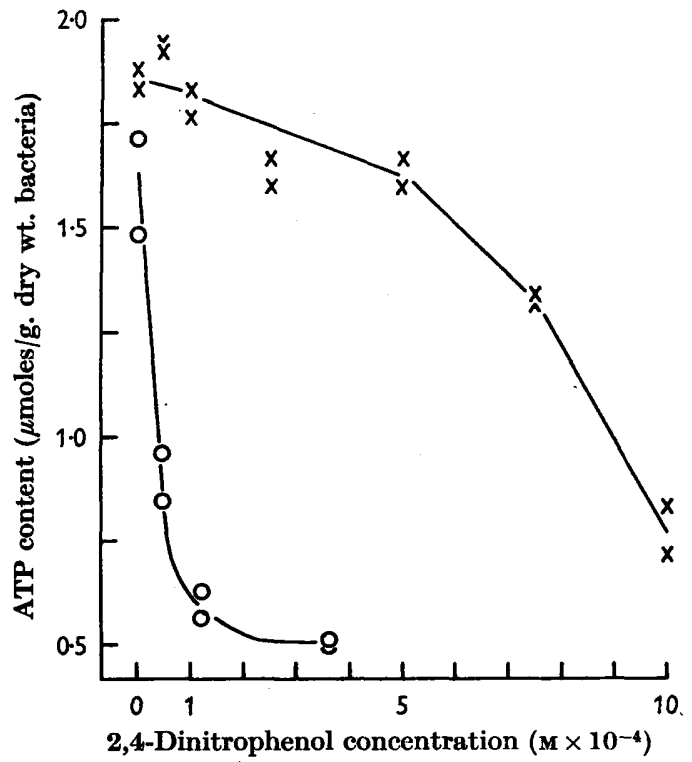

Fig. 1

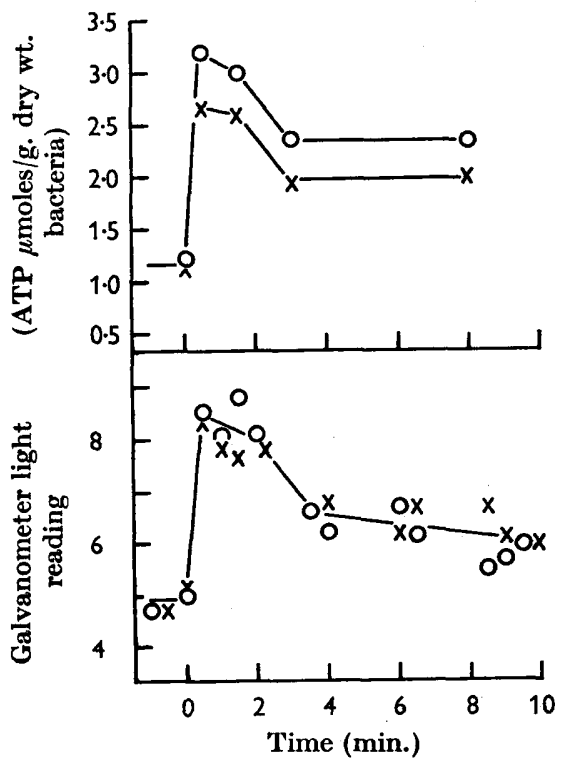

Fig. 2

Fig. 1. Effect of various concentrations of 2,4-dinitrophenol on ATP content of thiobacillus strain c oxidizing thiosulphate or sulphide. $2 \cdot 7 \mathrm{mg}$. dry wt. bacteria/ml. were shaken at $21^{\circ}$ for $15 \mathrm{~min}$. with the DNP concentration indicated. 8.3 $\mu$ moles $\mathrm{Na}_{2} \mathrm{~S}_{2} \mathrm{O}_{3} / \mathrm{ml}$. $(-x-x-)$ or $0.83 \mu$ mole $\mathrm{Na}_{2} \mathrm{~S} / \mathrm{ml}$. $(-\mathrm{O}-\mathrm{O}-)$ were added. $\mathrm{HClO}_{4}$ was added to the thiosulphate series after $6 \mathrm{~min}$. and to the sulphide series after $1 \mathrm{~min}$. Endogenous ATP content ( \pm DNP) was about $0 \cdot 70 \mu$ mole/g. dry wt.

Fig. 2. Effect of carbon dioxide on ATP concentrations during thiosulphate oxidation. Upper graph: $4.6 \mathrm{mg}$. bacteria in $2.4 \mathrm{ml}$. phosphate (pH $7 \cdot 0$ ) shaken in sealed $50 \mathrm{ml}$. flasks at $21^{\circ}$. One series $(-\mathrm{O}-\mathrm{O}-)$ had $0.4 \mathrm{ml} .40 \%(\mathrm{w} / \mathrm{v}) \mathrm{KOH}$ and a roll of filter paper in a centre well in each flask; the other series $(-x-x-)$ had $4 \mu$ moles $\mathrm{NaHCO}_{3} . \mathrm{Na}_{2} \mathrm{~S}_{2} \mathrm{O}_{3}$ was injected at time 0 . Lower graph: bacterial suspensions in a rapid-sampling device were aerated at $22^{\circ}$ with $\mathrm{CO}_{2}$-free air $(-x-x-)$ or $1 \%(v / v) \mathrm{CO}_{2}$ in air $\left(-\mathrm{O}_{-} \mathrm{O}-\right)$ and received $\mathrm{Na}_{2} \mathrm{~S}_{2} \mathrm{O}_{3}$ at time 0 .

\section{Simultaneous determination of ${ }^{14} \mathrm{CO}^{2}$ fixation and $\mathrm{ATP}$ content of bacteria oxidizing thiosulphate}

The rate of ${ }^{14} \mathrm{CO}_{2}$-fixation during thiosulphate oxidation was not constant from zero time, but always increased to a steady rate $2-3 \mathrm{~min}$. after substrate addition (Fig. 3). Since ATP formation was virtually instantaneous (Fig. 3) the phenomenon could not be attributed to a delay in thiosulphate metabolism. The addition of a second quantity of thiosulphate after the oxidation of the first resulted in renewed 
$\mathrm{CO}_{2}$-fixation at an instantaneously high rate (Kelly, 1965). Possibly, therefore, the initially low rate represented the time required to build up a steady-state intracellular concentration of $\mathrm{CO}_{2}$-acceptor molecules, such as ribulose diphosphate.

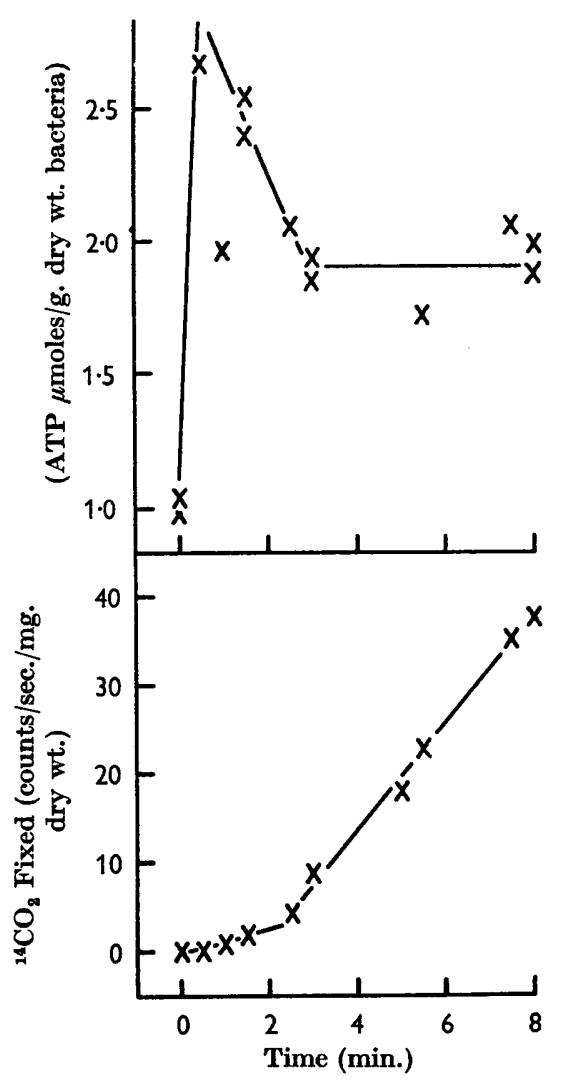

Fig. 3

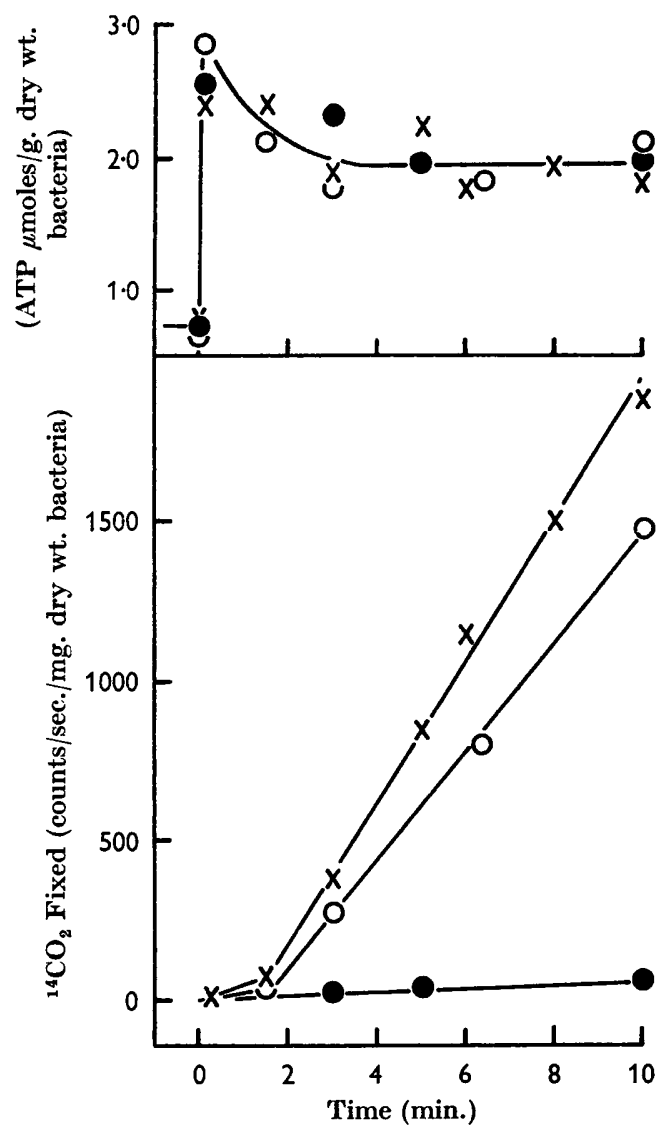

Fig. 4

Fig. 3. Simultaneous measurement of ${ }^{14} \mathrm{CO}_{2}$-fixation and ATP content during thiosulphate oxidation by thiobacillus strain c. Upper: ATP content; and lower: ${ }^{14} \mathrm{CO}_{2}$ fixed by dense bacterial suspensions shaken in sealed flasks into which $\mathrm{KH}^{14} \mathrm{CO}_{3}$ and $\mathrm{Na}_{2} \mathrm{~S}_{2} \mathrm{O}_{3}$ were injected at time 0 . Temp. $21^{\circ} ; \mathrm{pH} 7 \cdot 0$.

Fig. 4. Effect of 2,4-dinitrophenol on ATP content (upper graph) and ${ }^{14} \mathrm{CO}_{2}$ fixation (lower graph) by thiobacillus strain c oxidizing thiosulphate. Dense bacterial suspensions received $\mathrm{KH}^{14} \mathrm{CO}_{3}$ and $\mathrm{Na}_{2} \mathrm{~S}_{2} \mathrm{O}_{3}$ at time 0 , after pre-incubation with no DNP $(-\times-\times-), 5 \times 10^{-5} \mathrm{M}-\mathrm{DNP}\left(-\mathrm{O}_{-} \mathrm{O}^{-}\right)$or $5 \times 10^{-4}-\mathrm{DNP}$ (-O-O-). Temperature $21^{\circ}$; pH $7 \cdot 0$.

\section{Effect of 2,4-dinitrophenol on ${ }^{14} \mathrm{CO}_{2}$-fixation and $\mathrm{ATP}$ content with thiosulphate or sulphide as substrate}

DNP depressed both the initial low rate of ${ }^{14} \mathrm{CO}_{2}$-fixation and the subsequent steady high rate during thiosulphate oxidation (Fig. 4). The effect of DNP on ${ }^{14} \mathrm{CO}_{2}$-fixation bore no obvious relationship to the ATP content of bacteria oxidizing thiosulphate, since the initial rapid increase in ATP and the subsequent values were 
not significantly altered by DNP (Fig. 4). Figure $5 a$ confirms that no simple relationship existed between ATP content and ${ }^{14} \mathrm{CO}_{2}$ fixed after oxidation of thiosulphate for a set time, with a range of DNP concentrations. ${ }^{14} \mathrm{CO}_{2}$-fixation was $90 \%$ inhibited by a DNP concentration (0.2-0.3 mM) which only slightly lowered the ATP content. Even a DNP concentration which completely inhibited $\mathrm{CO}_{2}$ fixation (0.75 mM) only decreased the increase of ATP content to $50 \%$ of the control level. However, the depression of the ATP content by DNP in bacteria oxidizing sulphide was similar to the relative inhibition of $\mathrm{CO}_{2}$-fixation during
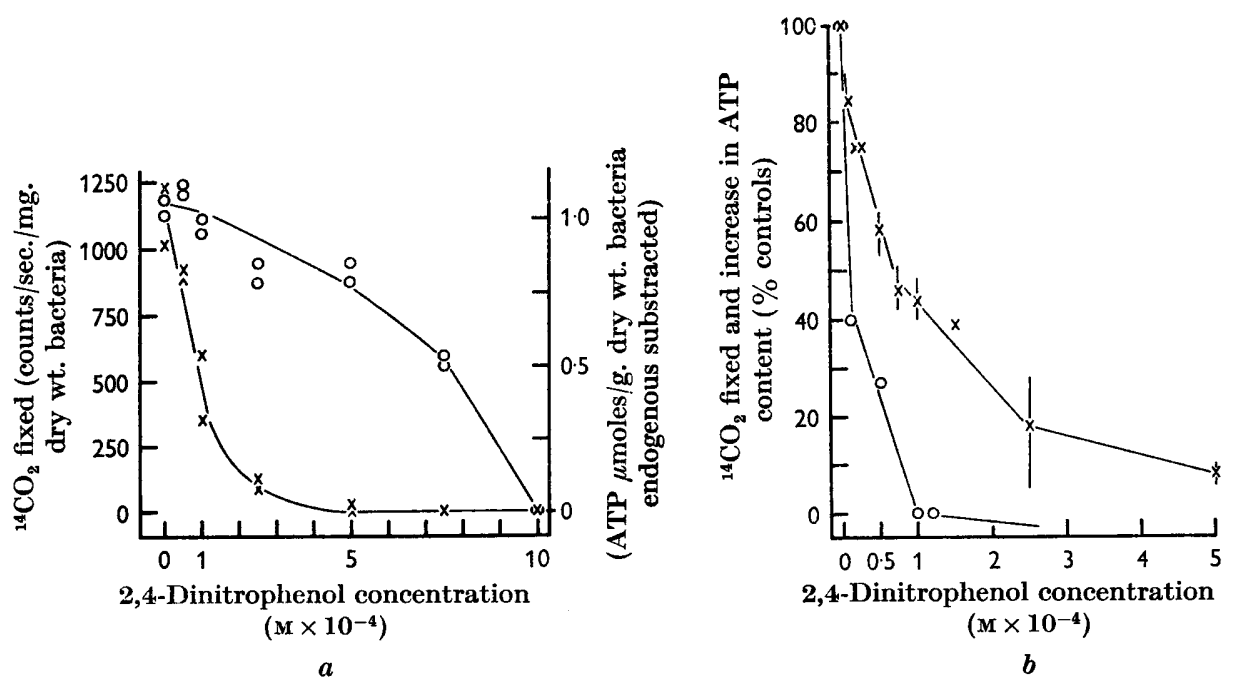

Fig. 5. Effect of various concentrations of 2,4-dinitrophenol on the ATP content (-O-O-) and ${ }^{14} \mathrm{CO}_{2}$ fixed $(-x-x-)$ by Thiobacillus strain $\mathrm{c}$ after oxidizing thiosulphate or sulphide: (a) Thiosulphate oxidized for 6 min. ATP content in excess of the endogenous value of $0 \cdot 8 \mu$ mole/g. dry wt. is shown. (b) Sulphide oxidized: ATP data are those obtained from two experiments after exposure of the thiobacilli to $\mathrm{Na}_{2} \mathrm{~S}$ for 60 or 90 sec. ${ }^{14} \mathrm{CO}_{2}$ data are derived from 1 to 7 separate experiments, and are values for total fixation during complete sulphide oxidation. Both values are expressed as $\%$ of control values. Vertical lines indicate the extreme values around the mean for ${ }^{14} \mathrm{CO}_{2}$ fixation. ATP values were calculated after subtraction of the endogenous ATP content in the absence of sulphide.

sulphide oxidation: Fig. $5 b$ shows the inhibition of ${ }^{14} \mathrm{CO}_{2}$-fixation in bacteria allowed to oxidize equal amounts of sulphide completely. These values were derived from several experiments, and are to be compared with the ATP content of bacteria which were allowed to oxidize sulphide for a set time in two experiments. Clearly the formation of ATP during sulphide oxidation was at least as sensitive to DNP as was the coupled $\mathrm{CO}_{2}$-fixation.

In a large number of experiments, DNP never inhibited oxygen uptake during sulphide oxidation. Thiosulphate oxidation by dilute suspensions was also unaffected or stimulated by DNP (Kelly \& Syrett, 1963, 1964a). By using thiosulphate labelled in the outer ('reduced') atom with ${ }^{35} \mathrm{~S}, 0 \cdot 1 \mathrm{~mm}$-DNP was found to have little effect on the kinetics of oxidation of the labelled atom by dense bacterial suspensions (in which oxidation was probably rate-limited by the concentration of dissolved oxygen). Figure 6 shows that labelled thiosulphate rapidly disappeared, with the parallel 
formation of sulphate and the transitory accumulation of labelled trithionate, which was unaffected by DNP. The subsequent oxidation of the trithionate to sulphate was, however, slightly retarded by DNP (see Kelly \& Syrett, 1964a).

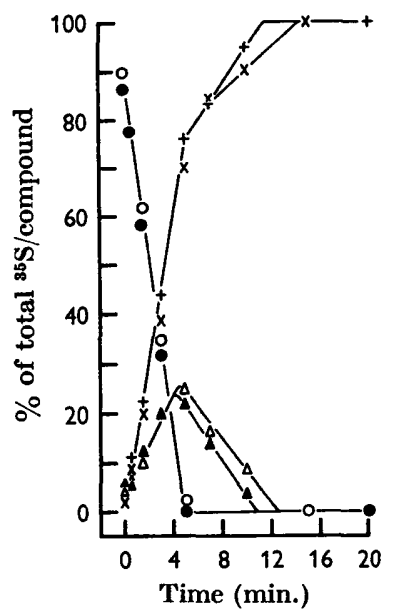

Fig. 6. Oxidation of $\mathrm{Na}_{2}\left({ }^{\mathrm{a}} \mathrm{S}_{\mathrm{S}} \mathrm{SO}_{8}\right)$ by thiobacillus strain $\mathrm{c}$ with and without $\mathrm{0} \cdot 1 \mathrm{~mm}-\mathrm{DNP}$. $250 \mathrm{ml}$. flasks shaken at $26^{\circ}$ contained in a final $12 \mathrm{ml}$. equiv. $33 \mathrm{mg}$. dry wt. bacteria; 1 mmole sodium phosphate, (pH 7.0); with or without DNP. $47 \mu$ moles $\mathrm{Na}_{2}\left({ }^{35} \mathrm{~S}_{\text {. }} \mathrm{SO}_{3}\right)$ $(23 \mu \mathrm{c})$ were added at zero time. Samples $(1 \mathrm{ml}$.) were pipetted into $1 \mathrm{ml}$. ethanol, centrifuged, and the supernatant fluids analysed chromatographically. With and without DNP, symbols are: $\mathrm{S}_{2} \mathrm{O}_{3}{ }^{2-}-\mathrm{O}-\mathrm{O}-$ and $-0-\mathrm{O}-\mathrm{SO}_{4}{ }^{2-}-x-x-$ and $-+-+-; \mathrm{S}_{3} \mathrm{O}_{6}{ }^{2-}-\triangle-\triangle$ and $-\mathbf{A}-\mathbf{A}-$.

Table 2. Effect of 2,4-dinitrophenol on ${ }^{14} \mathrm{CO}_{2}$-fixation coupled to the oxidation of sulphur, sulphide and thiosulphate by thiobacillus strain $C$

Warburg flasks contained in a final volume of $2.6 \mathrm{ml} .: 5 \mathrm{mg}$. dry wt. bacteria; $200 \mu$ moles sodium phosphate (pH 7); $6 \mu$ moles $\mathrm{KH}^{14} \mathrm{CO}_{3}(4 \mu \mathrm{c})$; the indicated DNP concentrations. After pre-incubation for 50 min., $10 \mu$ moles, $\mathrm{Na}_{2} \mathrm{~S}_{2} \mathrm{O}_{3}, 2.5 \mu$ moles $\mathrm{Na}_{2} \mathrm{~S}$ or 25 mg. elementary sulphur were added from the side arms. Temperature, $30^{\circ}$.

\begin{tabular}{|c|c|c|c|c|c|c|c|c|c|c|c|}
\hline \multirow{3}{*}{$\begin{array}{l}\text { DNP con- } \\
\text { centration } \\
(\mathrm{M})\end{array}$} & \multirow{3}{*}{$\begin{array}{c}\text { Initial } \\
\text { rate of } \\
\text { sulphur } \\
\text { oxidation } \\
\text { ( } \mu \text { l./hr/ } \\
\text { flask) }\end{array}$} & \multirow{3}{*}{$\begin{array}{l}\text { Oxygen } \\
\text { consumed in } \\
\text { sulphur } \\
\text { oxidation } \\
\text { ( } \mu \text { moles/ } \\
\text { flask) }\end{array}$} & \multirow{2}{*}{\multicolumn{3}{|c|}{$\begin{array}{c}{ }^{14} \mathrm{CO}_{2} \text { fixed } \\
\text { (counts/100 sec./flask) }\end{array}$}} & \multicolumn{6}{|c|}{$\begin{array}{l}{ }^{14} \mathrm{CO}_{2} \text { fixed } / \mu \text { mole or } \mu \text { g.atom } \\
\text { substrate oxidized* }\end{array}$} \\
\hline & & & & & & \multicolumn{3}{|c|}{ (Counts/100 sec.) } & \multicolumn{3}{|c|}{$(\%)$} \\
\hline & & & $\mathbf{S}^{\circ}$ & $\mathbf{S}^{2-}$ & $\mathrm{S}_{2} \mathrm{O}_{3}{ }^{2-}$ & $\mathbf{S}^{\circ}$ & $\mathbf{S}^{2-}$ & $\mathrm{S}_{2} \mathrm{O}_{3}{ }^{2-}$ & $\mathbf{S}^{\circ}$ & $\mathbf{S}^{2-}$ & $\mathrm{S}_{2} \mathrm{O}_{3}{ }^{2-}$ \\
\hline $\mathbf{0}$ & 58 & $13 \cdot 84$ & 46,400 & 27,200 & 172,500 & 5,040 & 10,880 & 17,250 & 100 & 100 & 100 \\
\hline $1 \times 10^{-5}$ & 58 & $13 \cdot 80$ & 26,800 & - & - & 2,920 & - & - & 58 & - & - \\
\hline $5 \times 10^{-5}$ & 62 & 14.42 & 22,000 & 18,900 & 126,000 & 2,280 & 7,560 & 12,600 & 45 & 69 & 73 \\
\hline $1 \times 10^{-4}$ & 54 & $13 \cdot 17$ & 13,600 & - & - & 1,540 & - & - & 31 & - & - \\
\hline$\times 10^{-4}$ & & $12 \cdot 37$ & 0 & 7,700 &, 000 & 8 & 80 & 900 & 17 & 28 & \\
\hline
\end{tabular}

* Calculated for sulphur oxidation as $1.5 \mu$ moles $\mathrm{O}_{2} \equiv 1 \mu \mathrm{g}$.atom $\mathrm{S}^{\circ}$, from: $\mathrm{S}^{\circ}+\mathrm{H}_{2} \mathrm{O}+\frac{3}{2} \mathrm{O}_{2}=\mathrm{H}_{2} \mathrm{SO}_{4}$.

Comparison of the effect of 2,4-dinitrophenol on ${ }^{14} \mathrm{CO}_{2}$-fixation with sulphide, thiosulphate or elementary sulphur as substrate

DNP had virtually no effect on the oxidation of elementary sulphur, but inhibited $\mathrm{CO}_{2}$-fixation more than when sulphide or thiosulphate was oxidized (Table 2). The significance of this result in understanding the energy-coupling process is uncertain. 
The relative amounts of $\mathrm{CO}_{2}$ fixed during the oxidation of $1 \mu$ mole thiosulphate or sulphide and $1 \mu$ atom sulphur (calculated from oxygen consumed) were 100, 63 and 29, respectively, in this experiment.

\section{DISCUSSION}

These results show clearly that the addition of sulphide or thiosulphate to an aerobic suspension of Thiobacillus sp. strain $\mathrm{c}$ was followed within 10 sec. by the synthesis of ATP. But whereas the ATP synthesis which accompanied the thiosulphate oxidation was quite unaffected by the presence of $0 \cdot 1 \mathrm{mm-2,4-dinitrophenol}$ (DNP), that which accompanied the sulphide oxidation was strongly inhibited. These observations support the view that in this Thiobacillus, ATP can be synthesized by at least two different mechanisms, only one of which is inhibited by DNP. The sensitive mechanism appears to be the major one coupled to sulphide oxidation, at least in its early stages. At present the most probable interpretation is that the mechanism sensitive to DNP inhibition is similar to oxidative phosphorylation in mitochondria which is also inhibited by similar concentrations of DNP (Loomis \& Lipmann, 1948). When thiosulphate is oxidized, the mechanism of ATP formation which is insensitive to DNP may well be that which Peck (1960) showed could accompany the oxidation of sulphite to sulphate by cell-free extracts of Thiobacillus thioparus. With these extracts, Peck showed that sulphite could be formed by the reductive cleavage of thiosulphate. Our results certainly suggest that the DNPinsensitive phosphorylation studied by Peck takes place in intact organisms and that therefore sulphite is an intermediate in thiosulphate oxidation. Whole organisms of Thiobacillus sp. strain c do not oxidize exogenous sulphite, possibly because it does not enter the organisms, so that the coupling of ATP formation to sulphite oxidation cannot be observed directly. From our results we cannot conclude anything about the origin of sulphite. It might be formed by reductive cleavage of thiosulphate, as Peck suggests, or by oxidation through a polythionate (London \& Rittenberg, 1964).

ATP is required to drive the reactions of the Calvin cycle by which carbon dioxide appears to be fixed by Thiobacillus (Trudinger, 1956; Aubert, Milhaud \& Millet, 1957). One might have expected, then, that in the presence of carbon dioxide the steady-state value of ATP would be lower. That this was not so presumably indicates that ATP formation coupled to thiosulphate oxidation was so rapid that the ATP concentration was maintained at its maximum value in spite of utilization by the carbon-dioxide fixation reactions.

When sulphide is the substrate, the effect of DNP is to decrease both the steadystate concentration of ATP and the rate of fixation of carbon dioxide and it is possible that the rate of carbon-dioxide fixation is limited by the amount of ATP available (Fig. $5 b$ ). But this cannot be so when thiosulphate is the substrate. Here the effect of DNP on carbon-dioxide-fixation, while less marked than when sulphide is the substrate, is nevertheless far greater than its effect on the steady-state level of ATP (Fig. 5a). In the presence of DNP the rate of carbon dioxide fixation must be limited by something other than the availability of ATP. This limiting factor could be the availability of reduced nicotinamide adenine dinucleotides, whose formation might require $\mathrm{NAD}(\mathrm{P})$ reduction with electrons from cytochromes reduced during thiosulphate oxidation (Aleem, 1965). Certainly, NAD reduction by reduced cyto- 
chromes in mitochondria is dependent on ATP or a high energy compound (Chance, 1961; Danielson \& Ernster, 1963) and is inhibited by DNP (Chance \& Hollunger, 1963).

We have concluded earlier (Kelly \& Syrett, 1964a) from the effect of DNP on carbon-dioxide-fixation that both DNP-insensitive and DNP-sensitive phosphorylations accompany thiosulphate oxidation. The decrease in the steady-state concentration of ATP at higher DNP concentrations with thiosulphate as substrate (Fig. 5), may indicate such a DNP-sensitive mechanism. However, the DNP concentrations producing the decrease are too high, in comparison with those affecting sulphide-dependent ATP synthesis, for this conclusion to be accepted with confidence. It is now clear, from the results presented in this paper, that the rate of carbon-dioxide-fixation is not a satisfactory index of ATP content when thiosulphate is the substrate. It may well be that thiosulphate oxidation is accompanied by both types of phosphorylation, but neither our results on carbon-dioxide-fixation nor those on ATP formation demonstrate this. Similarly, when sulphide is oxidized, it seems clear that the ATP formed initially is synthesized by a DNP-sensitive mechanism, but this does not rule out the participation of DNP-insensitive phosphorylation at a later stage in sulphide metabolism, perhaps at the level of sulphite oxidation.

\section{REFERENCES}

Aleem, M. I. H. (1965). Chemosynthesis and assimilatory power in Thiobacillus novellus Bact. Proc. p. 10.

Aleem, M. I. H., Lees, H. \& Nicholas, D. J. D. (1963). ATP dependent reduction of $\mathrm{NAD}$ by ferrocytochrome $\mathrm{C}$ in chemo-autotrophic bacteria. Nature, Lond. $200,759$.

Aubert, J. P., Milhaud, G. \& Milnet, J. (1957). L'assimilation de l'anhydride carbonique par les bactéries chimio-autotrophes. Ann. Inst. Pasteur, 92, 515.

Chance, B. (1961). Energy-linked cytochrome oxidation in mitochondria. Nature, Lond. 189,719 .

Chance, B. \& Hollunger, G. (1963). Inhibition of electron and energy transfer in mitochondria. IV. Inhibition of energy linked DPN reduction by uncoupling agents. J. biol. Chem. 238, 445.

Danielson, L. \& Ernster, L. (1963). Energy-dependent reduction of TPN by DPNH. In B. Chance: Energy-linked functions of mitochondria, p. 157.

Jornson, E. J. \& PECK, H. D., Jun. (1965). Coupling of phosphorylation and carbon dioxide fixation in extracts of Thiobacillus thioparus. J. Bact. 89, 1041.

KeLly, D. P. (1965). Energy metabolism of the chemoautotrophic bacterium, Thiobacillus. Ph.D. thesis, University of London.

Kelly, D. P. \& Sxrett, P. J. (1963). Effect of 2:4-dinitrophenol on carbon dioxide fixation by a Thiobacillus. Nature, Lond. 197, 1087.

Kelly, D. P. \& SYretT, P. J. (1964a). The effect of uncoupling agents on carbon dioxide fixation by a Thiobacillus. J. gen. Microbiol. 34, 307.

Kelly, D. P. \& SYretT, P. J. (1964b). Inhibition of formation of adenosine triphosphate in Thiobacillus thioparus by $2: 4-$ dinitrophenol. Nature, Lond. $202,597$.

Kelly, D. P. \& Syrett, P. J. (1966). [ ${ }^{35}$ S]Thiosulphate oxidation by Thiobacillus strain C. Biochem. $J$. (in the Press).

London, J. \& Rittenberg, S. C. (1964). Path of sulphur in sulfide and thiosulfate oxidation by Thiobacilli. Proc. natn. Acad. Sci., U.S.A. 52, 1183.

Loomis, W. F. \& LipmanN, F. (1948). Reversible inhibition of the coupling between phosphorylation and oxidation. J. biol. Chem. 173, 807.

Milhaud, G., Aubert, J. P. \& Miluet, J. (1957). Synthèse de l'adenosine 5'-triphosphate couplée à l'oxydation du thiosulfate par la bactérie chimioautotrophe Thiobacillus denitrificans. C.r. hebd. Séanc. Acad. Sci., Paris, 244, 1289. 
PECK, H. D., Jun. (1960). Adenosine $5^{\prime}$-phosphosulfate as an intermediate in the oxidation of thiosulfate by Thiobacillus thioparus. Proc. natn. Acad. Sci., U.S.A. 46, 1053.

Peck, H. D., Jun. (1962). Comparative metabolism of inorganic sulfur compounds in microorganisms. Bact. Rev. 26, 67.

Peck, H. D., Jun. \& Fisher, E., Jun. (1962). The oxidation of thiosulfate and phosphorylation in extracts of Thiobacillus thioparus. J. biol. Chem. 237, 190.

Strenuer, B. L. \& Totrer, J. R. (1952). Firefly luminescence in the study of energy transfer mechanisms. Archs Biochem. Biophys. 40, 28.

Syrett, P. J., Bocks, S. M. \& Merrett, M. J. (1964). The assimilation of acetate by Chlorella vulgaris. J. exp. Bot. $15,35$.

Trudinger, P. A. (1956). Fixation of carbon dioxide by extracts of the strict autotroph Thiobacillus denitrificans. Biochem. J. 64, 274.

Vishniac, W. \& Santer, M. (1957). The Thiobacilli. Bact. Rev. 21, 195.

Vogler, K. G. \& Umbreit, W. W. (1942). Studies on the metabolism of the autotrophic bacteria. III. The nature of the energy storage material active in the chemosynthetic process. J. gen. Physiol. 26, 157. 